\title{
PROBLEMATIKA KETERAMPILAN MENULIS SISWA KOTA JOMBANG DALAM PEMBELAJARAN BAHASA INDONESIA SECARA DARING
}

\author{
Yulianah Prihatin', Raras Hafiidha Sari ${ }^{2}$ \\ 1Universitas Hasyim Asy'ari: yuliaana553@gmail.com \\ 2 Universitas Hasyim Asy’ari: rarashhafiidha@gmail.com
}

\section{Artikel Info}

Received : 05 Okt2021

Accepted : 30 Okt 2021

Published : 29 Nov 2021
Abstrak

This study aims to describe the problems of students writing skills in learning Indonesian and offer solutions to solve them. This study uses a qualitative approach with a descriptive method. Data collection techniques using online interview techniques, listen and take notes. Interviews were conducted with students from elementary school (SD), junior high school (SMP), and high school (SMA) as well as Indonesian language teachers in Jombang Regency. Schools were selected randomly, namely SDN Jombatan, SMPN 5 Jombang, and SMA Wahid Hasyim. In addition, data was also obtained from a questionnaire distributed using google forms. Based on the results of the study, several problems were found, namely unattractive teaching materials, technological stuttering and availability of facilities, fear of starting, copy paste culture, and learning assessment. These problems certainly require solutions, including: preparing interesting teaching materials, providing technological facilities, and using portfolio assessments.

Keywords:problematic, writing skill

\section{A. PENDAHULUAN}

Pembelajaran daring atau jarak jauh (PJJ) menimbulkan banyak permasalahan dalam pelaksanaanya. Dwi, dkk (2020) dalam penelitiannya, menjelaskan bahwa pembelajaran online atau daring sangat tidak efektif dikarenakan faktor kurangnya sarana dan prasarana serta ketidaksiapan edukasi teknologi. Selain penelitian tersebut, masih ada beberapa penelitian lain yang berhubungan dengan keefektifan pembelajaran secara daring. Salah satunya adalah penelitian yang dilakukan oleh Surahman, F.dkk (2021) yang menjelaskan bahwa proses pembelajaran daring memiliki banyak kendala, seperti siswa masih telat dalam pengumpulan tugas, pembelajran tidak bisa disampaikan secara efektif.

Hal ini pula yang terjadi pada pembelajaran bahasa Indonesia. Dalam proses pembelajaran bahasa Indonesia, siswa dituntut untuk menguasai dan 
mengembangkan empat keterampilan berbahasa, yaitu keterampilan menyimak, keterampilan berbicara, keterampilan membaca, dan keterampilan menulis. Keempat aspek berbahasa tersebut sebisa mungkin harus dikuasai dan dikembangkan oleh siswa.

Nugraheni dan Rifka (2016:2) mengungkapkan bahwa pembelajaran bahasa Indonesia diharapkan membantu peserta didik mengenal dirinya, budayanya dan budaya orang lain, mengemukakan gagasan dan perasaan, berpartisipasi dalam masyarakat yang menggunakan bahasa tersebut dan menemukan serta menggunakan kemampuan analitis dan imaginatif yang ada dalam dirinya. Pembelajaran bahasa Indonesia diarahkan untuk meningkatkan kemampuan peserta didik dalam berkomunikasi dengan bahasa Indonesia yang baik dan benar baik secara lisan maupun tulis, serta menumbuhkan apresiasi terhadap hasil karya kesastraan manusia Indonesia seperti tujuan dari Peraturan Menteri Pendidikan Nasional Nomor 22 Tahun 2006.

Salah satu dari empat keterampilan berbahasa itu adalah keterampilan menulis. Keterampilan menulis merupakan salah satu jenis keterampilan berbahasa yang harus dikuasai siswa. Banyak ahli telah mengemukakan pengertian menulis. Keterampilan menulis adalah kemampuan mengungkapkan gagasan, pendapat, dan perasaan kepada pihak lain dengan melalui bahasa tulis. Ketepatan pengungkapan gagasan harus didukung dengan ketepatan bahasa yang digunakan, kosakata dan gramatikal dan penggunaan ejaan.

Menulis merupakan kegiatan mengubah bunyi menjadi tulisan sebagai upaya untuk mengungkapkan gagasan untuk mengungkapkan gagasan menjadi bahasa tulis memerlukan sejumlah potensi pendukung yang untuk mencapainya dibutuhkan kesungguhan, kemauan keras, bahkan belajar dengan sungguhsungguh, (Nursisto, 1999:4)

Setiap penulis harus mempunyai tujuan yang jelas dari tulisan yang akan ditulisnya. Tujuan dari menulis adalah agar tulisan yang dibuat dapat dibaca dan dipahami dengan benar oleh orang lain yang mempunyai kesamaan pengertian terhadap bahasa yang dipergunakan. Sedangkan, menurut Suparno dan Mohamad Yunus (2008: 3.7), tujuan yang ingin dicapai seorang penulis bermacam-macam sebagai berikut: 1) Menjadikan pembaca ikut berpikir dan bernalar. 2) Membuat pembaca tahu tentang hal yang diberitakan. 3) Menjadikan pembaca beropini. 4) Menjadikan pembaca mengerti. 5) Membuat pembaca terpersuasi oleh isi karangan. 6) Membuat pembaca senang dengan menghayati nilai-nilai yang dikemukakan seperti nilai kebenaran, nilai agama, nilai pendidikan, nilai sosial, nilai moral, nilai kemanusiaan dan nilai estetika.

Trismanto (2017:62) menyatakan bahwa ketidaksukaan peserta didik dengan kegiatan menulis adalah karena adanya kekeliruan pemahaman esensi mengenai konsep menulis. Yunus (2007:1) mendefinisikan menulis sebagai kegiatan komunikasi dengan menggunakan bahasa tulis sebagai medianya. Sayangnya, tidak banyak diantara peserta didik bahkan guru sekalipun tidak menyukai aktivitas menulis atau mengarang. Kasupardi (2012: 6) mengungkapkan bahwa terdapat enam fungsi tulisan.

Pertama, fungsi infomratif yakni tulisan dapat memberikan informasi tentang tulisan yang lebih tertuju sebagai sarana pendidikan. Kedua, fungsi direktif yaitu tulisan dapat digunakan untuk mengatur tingkah laku orang lain. Ketiga, fungsi interaksional atau interpersonal yaitu tulisan mempunyai fungsi untuk menjalin hubungan sosial. Kemapat, fungsi imajinatif, artinya penulis menggunakan bahasa tulis untuk menyampaikan pikiran, gagasan, dan perasaan baik yang sebenarnya maupun yang hanya hasil imajinasinya saja. Kelima, fungsi emotif yang artinya tulisan merupakan tempat bagi penulis untuk mengungkapkan emosi lewat bahasa tulisan. 
Iskandarwassid (2010) berpendapat bahwa keterampilan menulis, sebagai salah satu kemahiran berbahasa yang produktif ini, mendorong seseorang untuk menyampaikan ide, pikiran, keinginan dan perasaan kepada orang lain melalui bahasa tulis. Hal senada juga disampaikan oleh Zulkarnaini (2011) yang menyatakan bila dibandingkan dengan keterampilan berbahasa lainnya, sering sekali keterampilan menulis dianggap sebagai sebuah keterampilan yang paling sulit. Kegiatan menulis adalah suatu proses menurunkan lambang-lambang grafis dan aktivitas melahirkan gagasan, pikiran, perasaan, kepada pembaca melalui media bahasa berupa tulisan.

Membelajarkan menulis harus memperhatikan perkembangan menulis anak. Perkembangan anak dalam menulis terjadi secara perlahan - lahan. Anak perlu mendapatkan bimbingan dalam memahami dan menguasai cara mentransfer pikiran ke dalam tulisan. Menurut Temple (Zuchdi, 2008), perkembangan tulisan anak meliputi 4 tahap sebagai berikut.

Pertama. Tahap prafonemik. Pada tahap ini anak sudah mengenal bentuk dan ukuran huruf tetapi belum bisa menyusunnya untuk menulis kata. Anak belum bisa mengetahui prinsip fonetik yakni huruf mewakili bunyi-bunyi yang membentuk kata.

Kedua, Tahap fonemik awal, pada tahap ini anak sudah mengenali prinsip fonetik, tahu cara kerja tulisan tetapi belum bisa mengoperasikan prinsip tersebut. Tahap nama huruf. Pada tahap ini, anak sudah bisa menggunakan prinsip fonetik , dia dapat menggunakan huruf-huruf yang mewakili bunyi-bunyi yang membentuk suatu kata.

Ketiga, tahap transisi Tahap ini ditandai dengan penguasaan anak terhadap tata tulis yang semakin lengkap, dia juga sudah bisa menggunakan ejaan dan tanda baca dalam tulisan.

Dalam pembelajaran keterampilan menulis secara daring, siswa tetap harus memenuhi tujuan pembelajaran. Hal itu bisa dicapai saah satunya dengan mengikuti pembelajaran yang kondusif. Samsiyah (2016) menyatakan bahwa untuk memiliki keterampilan menulis, tidak terlepas dari proses membaca menyimak dan berbicara. Namun, saat kondisi pandemic yang mengharuskan pembelajaran secara daring, pembelajaran menulis di sekolah belum sepenuhnya mendapat perhatian.

Banyak problematika yang dialami, khususnya yang dialami oleh siswa di beberapa sekolah di kabupaten Jombang. Oleh karena itu, dalam penelitian ini bertujuan untuk mendeskripsikan problematika keterampilan menulis siswa dalam pembelajaran bahasa Indonesia secara daring serta solusi pemecahannya.

\section{B. METODE PENELITIAN}

Penelitian ini menggunakan pendekatan kualitatif dan metode deskriptif. Penelitian ini dimaksudkan untuk memperoleh deskripsi problematika keterampilan menulis dalam pembelajaran Bahasa Indonesia secara daring. Peneliti mendeskripsikan problematika siswa dalam pembelajaran Bahasa Indonesia secara daring dan memberikan solusi untuk mengatasinya.

Teknik pengumpulan data pada penelitian ini menggunakan teknik wawancara secara online dan pengisian angket menggunakan Google Formulir, teknik simak, catat dan dokumentasi. Wawancara online dilakukan kepada guru Bahasa Indonesia, siswa dan orang tua siswa. Wawancara dilakukan kepada siswa dari jenjang sekolah dasar (SD), sekolah menengah pertama (SMP), dan sekolah menengah atas (SMA) serta guru Bahasa 
Indonesia di Kabupaten Jombang. Pemilihan sekolah dilakukan secara random yaitu SDN Jombatan, SMPN 5 Jombang, dan SMA Wahid Hasyim. Selain itu data juga didapatkan dari angket yang disebarkan pada subjek menggunakan google form. Adapun objek penelitiannya yaitu proses pembelajaran Bahasa Indonesia.

\section{HASIL DAN PEMBAHASAN}

\section{Problematika Keterampilan Menulis Siswa dalam Pembelajaran Bahasa Indonesia Secara Daring di Jombang}

\section{a) Bahan Ajar yang Tidak Menarik}

Salah satu problematika dalam keterampilan menulis yang disampaikan oleh siswa dan beberapa orang tua selama mendampingi anaknya dalam pembelajaran daring adalah bahan ajar yang digunakan guru tidak menarik. Aktivitas guru di kelas tidak didukung dengan bahan ajar menulis yang kreatif, padahal dilihat dari karakteristik peserta didik. Peserta didik sangat membutuhkan penjelasan dan bahan ajar dari guru untuk dapat belajar lebih dalam mengenai menulis secara mandiri di rumah. Seperti yang diketahui saat ini, kebanyakan guru beranggapan bahwa menulis hanyalah sebatas pemberian tugas yang kemudian dikumpulkan dan dinilai tanpa diberi pembinaan. Tidak sedikit guru yang hanya berfokus pada hasil tulisan peserta didik tanpa secara aktif membimbing dalam proses menulis. Hal tersebut membuat peserta didik merasa bahwa menulis masih menjadi suatu beban bukan suatu wadah mereka untuk menyalurkan ide.

\section{b) Gagap Teknologi dan Ketersediaan Fasilitas}

Problematika pertama yang dialami saat pembelajaran secara jarak jauh adalah gagap teknologi dan ketersediaan fasilitas seperti HP, laptop, jaringan telepon seluler.
Beberapa orang tua dan siswa menyatakan bahwa mereka kesulitan mengikuti pembelajaran jarak jauh dikarenakan tidak memiliki HP atau laptop. Saat ini, HP memang sudah menjadi barang yang tidak asing lagi dan menjadi kebutuhan wajib, namun di beberapa daerah masih banyak siswa yang belum memiliki benda tersebut. Pembelajaran jarak jauh yang mengharuskan antar komponen terhubung, mewajibkan orang tua harus menyisihkan uang agar bisa membelikan anaknya HP dengan tujuan agar anak bisa mengikuti sekolah daring. Ternyata, hal itu juga dialami oleh beberapa orang tua di daerah lain. Dikutip dari SuaraJawaTengah.id (2021) menjelaskan bahwa seorang ibu membelikan HP anaknya dengan cara membuka tabungan yang dikumpulkan beberapa bulan dengan uang receh, demi anaknya bisa mengikuti sekolah daring.

Selain mengharuskan siswa mempunyai HP atau laptop, pembelajaran jarak jauh juga mengharuskan agar siswa dan guru memiliki koneksi jaringan yang bagus demi kelancaran pelaksanaan pembelajaran. Namun, jika dilihat di lapangan, masih ada beberapa daerah yang belum memiliki koneksi internet yang memadai seperti di daerah 3T. Berdasarkan data dari Asosiasi Penyelenggara Jasa Internet Indonesia (APJII), jumlah pengguna internet di Indonesia sebanyak 143,26 juta atau sekitar $55 \%$ dari populasi. Artinya masih terdapat $45 \%$ masyarakat yang tidak tersentuh internet (kominfo.go.id, 2018).

Tidak hanya itu, siswa dari keluarga yang memiliki ekonomi menengah ke bawah juga terkendala dalam hal pengadaan pulsa/paket internet/kuota untuk mengikuti pembelajaran daring. Namun, pemerintah berusaha menyediakan solusi atas permasalahan ini, yaitu dengan memberikan bantuan kuota internet bagi siswa maupun guru. Meskipun, masih ada beberapa siswa 
dan guru yang tidak terdata sehingga tidak mendapatkan bantuan.

Selain ketersediaan fasilitas, yang menjadi problematika utama adalah teknologi. Tidak dapat dipungkiri, bahwa sistem pembelajaran daring merupakan suatu hal baru bagi kebanyakan guru, siswa dan orang tua. Pembelajaran secara konvensional (tatap muka) yang selama ini mereka dilakukan, sudah dianggap yang paling nyaman. Tetapi dengan munculnya wabah Covid-19 yang sampai saat ini belum mereda, mau tak mau sistem pembelajaran konvensional itu dipaksa berubah. Jika sebelum pandemi, pembelajaran dilakukan dengan tatap muka di ruang kelas. Maka dimasa pandemi pembelajaran mesti dilakukan secara daring tanpa bertatap muka secara langsung. Selain berpisah secara fisik, pembelajaran secara daring membutuhkan pengetahuan serta kemampuan tentang internet dan teknologi informasi serta komunikasi yang baik.

Di satu sisi, guru mesti mampu menyiapkan desain pembelajaran dan materi yang cocok disajikan secara daring serta mampu menguasai teknologi informasi dan komunikasi (TIK) untuk melaksanakannya. Tapi di sisi lain, siswa dituntut menguasai teknologi informasi untuk mengikuti pembelajaran tersebut. Mungkin bagi sebagian guru dan siswa, tidak kesulitan menggunakan internet dalam pembelajaran daring. Tetapi bagi sebagian guru dan siswa yang masih gaptek (gagap teknologi) akan menjadi masalah. Walaupun mereka sudah memiliki telepon genggam pintar (smartphone), notebook atau laptop, namun belum pernah memanfaatkannya untuk pembelajaran daring. Kondisi seperti inilah yang kemudian memunculkan masalah baru. Berhubung pembelajaran secara daring sudah menjadi tuntutan dan kebutuhan dimasa pandemi Covid-19 ini, maka guru dan siswa mesti memaksakan diri mereka sendiri untuk belajar dan memahami teknologi informasi.

Penguasaan teknologi informasi ini menjadi kewajiban bagi guru dan siswa bahkan orang tua. Oleh sebab itu, para guru dan siswa dihadapkan dengan tantangan baru yang mau tidak mau mesti mereka hadapi. Dengan berbagai cara, mereka berusaha belajar memahami dan menguasai teknologi informasi serta mengimplementasikannya dalam pembelajaran daring. Ada yang belajar secara mandiri dan ada juga yang belajar secara berkelompok di sekolah masingmasing. Akibatnya setelah mereka menguasai dan mampu menggunakan teknologi informasi dan Komunikasi (TIK) dalam pembelajaran daring, mereka baru merasakan betapa dimudahkan dalam berbagai hal yang terkait dengan pembelajaran daring. Sebahagian guru, siswa dan orang tua yang selama ini kurang peduli terhadap pemanfaatan teknologi informasi untuk kegiatan proses belajar mengajar, sekarang sudah bisa merasakan sendiri manfaatnya. Ternyata dengan menggunakan teknologi mereka sangat dimudahkan dalam melaksanakan pembelajaran.

Teknologi informasi bukan hanya sebagai alat komunikasi, tetapi sekarang proses belajar mengajar menjadi semakin mudah dan fleksibel. Artinya, di satu sisi pandemi Covid-19 memang menimbulkan efek negatif, tetapi di sisi lain juga mampu memberikan efek positif bagi dunia pendidikan. Oleh sebab itu, jangan hanya dilihat dari sisi negatifnya saja. Pasti ada hikmah di balik musibah ini. Terbukti, setelah adanya wabah pandemi Covid-19, dunia pendidikan mengalami banyak kemajuan terutama pengetahuan di bidang teknologi.

Kemajuan teknologi informasi dan komunikasi semakin menunjang proses 
pembelajaran daring dengan hadirnya berbagai media (aplikasi) dan platform pembelajaran online. Media (aplikasi) yang dimaksud dan paling populer digunakan di kalangan guru, dosen, siswa dan mahasiswa diantaranya, WhatsApp Group, Google Classroom, Zoom Cloud Meeting, Edmodo, Google Meet, Quizizz, Webex, Loom dan Duolingo. Adanya (media) aplikasi dan platform pembelajaran online tersebut semakin menunjang peran teknologi informasi dan komunikasi pada proses pembelajaran. Peran atau manfaat teknologi informasi dan komunikasi pada bidang pendidikan atau pembelajaran daring adalah : sebagai infrastruktur pembelajaran, sebagai sumber bahan ajar, sebagai alat bantu dan fasilitas pembelajaran, sebagai skill dan kompetensi, sebagai sumber informasi penelitian, sebagai media konsultasi, dan sebagai media belajar online.

\section{c) Takut Memulai}

Sesuatu yang tidak pernah dimulai jelas tidak akan pernah selesai. Kebanyakan peserta didik takut memulai untuk menulis karena guru terlalu banyak tuntutan atas hasil tulisan peserta didik. Dengan begitu, peserta didik menjadi takut ditertawakan, takut membuat kesalahan, takut mendapatkan kritik apabila tulisannya tidak sesuai dengan tuntutan guru. Kedua, tidak tahu kapan harus memulai, Permasalahan seperti ini hadir dalam bentuk keluhan, yakni tidak tahu topik apa yang harus dikerjaan, dari mana mulai mengerjakan, dan bagaimana cara mengerjakannya. Ketiga, masalah penggunaan bahasa. Peserta didik masih saja sering keliru dalam penggunaan bahasa. Ditambah lagi, peserta didik yang memang tidak terbiasa menggunakan bahasa Indonesia, saat menulis sering kali mencampuradukkan bahasa Indonesia dengan bahasa daerahnya. Permasalahan bahasa ini juga terjadi dalam pemilihan kata yang sesuai dan ejaannya.

\section{d) Budaya Copy Paste}

Perkembangan zaman dan teknologi tentu memiliki dampak, baik dampak positif maupun dampak negatif. Salah satu dampak negatif penggunaan teknologi dalam keterampilan menulisa adalah semakin maraknya budaya copy paste di kalangan siswa Indonesia. Berdasarkan hasil wawancara dengan beberapa narusumber, mereka sring melakukan copy paste untuk mengerjakan tugas, terutama pada saat pembelajaran jarak jauh seperti ini. Kemajuan teknologi informasi memberikan ruang bebas bagi siswa untuk mencuri gagasan orang lain melalui internet. Tantangan lain adalah adanya budaya instan yang berkembang di masyarakat turut memperparah terjadinya praktik kotor tersebut. Kemudahan mengakses tulisan dari internet membuat siswa tidak perlu bersusah payah menghasilkan sebuah karya. Hal ini sebenarnya tamparan keras bagi dunia pendidikan.

Pendidikan dan sekolah memiliki tanggung jawab moral mengembangkan dan memperkuat karakter siswa dalam mempersiapkan bangsa yang maju dan beradab. Budaya copy paste merupakan salah satu praktik perilaku kotor yang membudaya di dunia pendidikan. Praktik ini banyak dilakukan oleh anak didik ketika melaksanakan tugas sekolah. Siswa cukup menulis nama pelajaran dan bab di laman pencarian, maka yang dicari akan langsung ketemu. Berdasarkan hasil wawancara, terdapat beberapa alasan siswa melakukan budaya copy paste. Diantaranya mereka tidak tahu apa yang harus ditulis, karena minimnya bahan literasi. Siswa kesulitan dalam merangkai kalimat yang baik. Siswa kurang percaya diri pada pilihan kata yang digunakan. Belum lagi waktu yang 
mendesak untuk mengumpulkan karya. Jalan pintas copy paste sebagai pilihan siswa yang cepat dan efektif untuk keluar dari permasalahan yang dihadapi.

e) Penilaian Pembelajaran

Penilaian dilakukan tidak hanya untuk menilai hasil belajar siswa melainkan juga menilai proses belajar siswa. Dalam melakukan evaluasi, ada beberapa hal yang harus diperhatikan guru terutama yang berhubungan dengan taksonomi tujuan pengajaran, teknik evaluasi, jenis tes yang akan digunakan, dan tujuan evaluasi yang dilakukan. Dengan demikian, evaluasi yang dilakukan menjadi terarah dan terencana. Dalam pembelajaran daring, khususnya pembelajaran keterampilan menulis. Guru merasa kesulitan dalam melakukan penilaian. Hal tersebut dikarenakan guru tidak bisa memantau langsung proses menulis yang dilakukan siswa. Sehingga untuk penilaian proses yang seharusnya dilakukan secara terarah tidak bisa dilakukan. Guru hanya melakukan penilain jika hasil tulisan sudah jadi. Padahal untuk menciptakan tulisan yang bagus, siswa harus melalui beberapa proses di dalamnya. Selain itu, selama pembelajaran daring, peran orang tua sangat besar dalam penyelesaian tugas anaknya. Berdasarkan hasil wawancara, orang tua lebih sering membantu anaknya menyelesaikan tugas dibandingkan membimbing untuk menyelesaikan tugas. Hal itu dilakukan dengan alasan, agar anaknya mendapatkan nilai bagus.

\section{Solusi Pemecahan Masalah}

a) Penyiapan Bahan Ajar Yang Menarik

Salah satu cara yang dapat digunakan untuk meningkatkan keterampilan menulis adalah menggunakan metode latihan dengan bantuan media gambar berseri. Hal tersebut seperti yang diungkapkan oleh Munah (2020). Hasil penelitian didapatkan simpulan bahwa penggunaan media gambar seri dalam proses pembelajaran dapat mempermudah siswa dalam menulis karangan sederhana, penggunaan media gambar seri dalam proses pembelajaran dapat meningkatkan kesungguhan belajar siswa yang berada pada tahap perkembangan kognitif operasional konkrit, ada korelasi positif antara kesungguhan belajar siswa dengan hasil belajar siswa. Semakin tinggi kesungguhan belajar siswa maka semakin tinggi pula angka keberhasilan siswa dalam belajar.

Selain itu, penelitian Pebriasari dan Purwanti (2014:56) mengungkapkan bahwa untuk meningkatkan keterampilan menulis dapat melalui model concept sentence yang berbantuan media visual. Model tersebut termasuk model pembelajaran inovatif berbasis kooperatif yang berarti menuntuk peserta didik untuk bekerja sama. Pembelajaran kooperatif mengarah pada metode pelaksanaan pengajaran dimana peserta didik bekerja dalam kelompokkelompok kecil untuk saling membantu temannya yang mengalami kesulitan dalam memahami materi pelajaran (Slavin, 2010:4).

Strategi lain yang bisa digunakan untuk meningkatkan menulis yaitu dengan menggunakan strategi Guiding Questions. Penelitian yang dilakukan oleh Amelia (2015) menghasilkan temuan bahwa teknik Guiding Questions dapat meningkatkan kemampuan menulis peserta didik di SMPN 35 Medan dengan peningkatan yang memuaskan. Penelitian lain yang serupa oleh Napitupulu (2015) juga mengemukakan bahwa kemampuan peserta didik dalam menulis teks deskripsi di SMP Tri Sakti Lubuk Pakam Sumatera Utara mengalami peningkatan dengan menggunakan teknik yang sama. Berdasarkan dua hasil penelitian sebelumnya tersebut, penulis mengharapkan teknik Guiding Questions juga akan meningkatkan kemampuan menulis peserta didik di SMKN 1 Singaraja. 
Agar peserta didik antusias untuk mengikuti pembelajran, guru harus pintarpintar memilih teks yang membangkitkan semangat peserta didik. Guru perlu menyediakan contoh teks yang sesuai dengan umur dan karakter peserta didik agar mereka dapat menyukai apa yang mereka baca. Namun, apabila diawal guru telah memberikan contoh teks yang tidak menarik perhatian peserta didik, misalnya dengan menyajikan teks yang tidak sesuai umur, atau teks yang terlalu sulit mereka pahami, akan berpengaruh pada proses pembelajaran selanjutnya.

b) Penyediaan Fasilitas Teknologi

Berkaitan dengan problematika gagap teknologi dan penyediaan fasilitas yang memadai dalam keterampilan menulis pembelajaran Bahasa Indonesia secara daring, maka perlu dilakukan adanya pelatihan serta penyediaan fasilitas yang memadai. Sekolah bisa bekerjasama dengan beberapa perguruan tinggi untuk mengadakan pelatihan berkenaan dengan pemanfaatan teknologi pendidikan. Meskipun memerlukan waktu dan persiapan dalam pelaksanaanya, namun cara ini bisa menjadi solusi agar pendidik bisa menggunakan platfor pembelajaran secara baik.

Selain bekerjasama dengan perguruan tinggi, sekolah juga bisa bekerjsama dengan beberapa pihak seperti dinas setempat untuk melakukan pelatihan yang serupa. Sedangkan, untuk penyediaan fasilitas atau sarana dan prasarana, tentu juga tidak bisa langsung melainkan membutuhkan waktu dalam pemenuhan kebutuhannya. Saat ini pemerintah juga sudah berupaya memberikan solusi berkaitan dengan penyediaan fasilitas, salah satunya adalah dengan memberikan bantuan kuota pulsa bagi siswa baik di jenjang TK sampai dengan perguruan tinggi. Hal itu salah satu upaya baik untuk menyelesaikan problematika yang berhubungan dengan fasilitas dalam pembelajaran daring.

\section{c) Penggunaan Penilian Portofolio}

Portofolio assessment merupakan upaya penilaian yang didasarkan pada kumpulan karya siswa yang terbaik pada suatu proses pembelajaran. Dari portofolio ini, guru akan memperoleh informasi penting tentang perkembangan kemajuan belajar siswa secara bertahap dan transparan. Hal ini bertujuan, melakukan tindak lanjut memperbaiki hasil belajar siswa. Prinsip dasar penilaian portofolio adalah penilaian proses dan hasil. Penilaian berskala dan berkesinambungan. Pada bagian penilaian proses inilah budaya copy paste bisa dicegah oleh guru dengan cara mengontrol hasil karya siswa. Guru memeriksa kemajuan tahap demi tahap hasil belajar siswa. Sehingga upaya ini bisa meminimalkan praktik copy paste di sekolah.

Tidak bisa dipungkiri, Guru memiliki peran dalam melestarikan budaya copy paste pada anak didik. Seringkali guru hanya memberi petunjuk tema tulisan. Kemudian siswa secara mandiri mengembangkan tema tersebut tanpa bimbingan dan kontrol dari guru. Kemudian yang terjadi adalah siswa memilih jalan pintas dengan mengambil dari internet. Menurut Suderajat dan Sumerna (Tsaur, Sufyan: 2009), alasan mengapa menggunakan penilaian portofolio karena salah satunya dapat mendokumentasikan proses pembelajaran yang berlangsung. Dari dokumentasi ini, guru dapat menilai dan mengetahui perkembangan menulis siswa yang pada akhirnya akan mengetahui mana yang merupakan hasil tulisan asli anak didiknya dan mana tulisan yang hanya copy paste dari internet.

Memang dibutuhkan kerja keras dari guru untuk meneliti satu persatu hasil karya siswa. Jika hal itu untuk kebaikan sistem pendidikan dan masa depan bangsa ini, mengapa tidak kita lakukan. Jika saja pada setiap pembelajaran khususnya materi menulis. Guru memiliki komitmen tinggi 
menerapkan sistem kontrol melalui portofolio, maka akan terwujudlah budaya jujur pada diri siswa masing-masing sehingga akan terwujud budaya mutu di sekolah itu. Dampak positif lain yang dirasakan siswa adalah mereka termotivasi berkarya lebih baik lagi. Sehingga budaya copy paste semakin lama akan terkikis dan bahkan hilang.

Satu hal penting yang wajib diketahui dari penerapan penilaian portofolio pada pembelajaran menulis ini adalah adanya upaya dari guru untuk menerapkan perilaku jujur dan tanggung jawab pada siswa. Bagaimana memaksimalkan peran sebagai guru untuk ambil bagian dalam pembangunan peradaban manusia yang lebih baik lagi melalui pembelajaran di kelas.

\section{D.SIMPULAN}

Berdasarkan hasil penelitian dan pembahasan, diperoleh beberapa problematika keterampilan menulis dalam pembelajaran bahasa Indonesia secara daring yaitu: bahan ajar yang tidak menarik, gagap teknologi dan ketersediaan fasilitas, takut memulai, budaya copy paste, dan penilaian pembelajaran. Problematika tersebut tentu memerlukan solusi pemecahannya, diantaranya yaitu: penyiapan bahan ajar yang menarik, penyediaan fasilitas teknologi, dan penggunaan penilaian portofolio.

\section{DAFTAR PUSTAKA}

Amelia, W. P. (2015). The Effect of Guiding Questions Technique on Students Achievement in Writing Dezcriptive Text. A GENRE Journal of Applied Linguistics of FBS Unimed.

Bonner,M. 1994. Step Into Writing, New York: Addison-Wesley Publishing Company., 1-11.
Dwi, dkk. (2020). Analisis Keefektifan Pembelajaran Online di Masa Pandemic Covid-19. MAHAGURU: Jurnal Pendidikan Guru Sekolah Dasar, Vol.2, No.2, 2020.

Iskandarwassid, \& Ristianti, I. (2010). Peningkatan kemampuan menulis narasi melalui model pembelajaran teknik visual-auditif-taktil. Jurnal Penelitian Ilmu Pendidikan, 11(1), 75-99.

Kasupardi, Endang. (2012). Pengembangan keterampilan menulis. Jakarta: Trans Mandiri Abad.

Munah, S. (2020. Peningkatan Keterampilan Menulis Karangan Sederhana Melalui Media Gambar Berseri pada Siswa Kelas III SD Negeri Mertasinga 02 Cilacap. Universitas Nahdlatul Ulama Al Ghazali (Unugha), hasil penelitian yang tidak dipublikasikan.

Nugraheni, Aninditya Sri dan Rifka. 2016. Studi Analisis Pembelajaran Bahasa Indonesia pada Siswa Berkesulitan Menulis (Dysgraphia) di SD Intis School Yogyakarta. LITERASI. Vol. VII, No. 1 Juni 2016.

Nursisto. (1999). Penuntun Mengarang. Yogyakarta: Adi Cita Karya Nusa.

Pebriasari, Lolita dan Eko Purwanti. (2014) Peningkatan keterampilan menulis karangan narasi melalui model concept sentence berbantuan media visual. Jurnal Unnes. Vol. 3: 1-5.

Peraturan Menteri Pendidikan Nasional Nomor 22 Tahun 2006.

Surahman, dkk. (2021). Analisis Proses Pembelajaran Daring pada Masa Pandemi Covid-19 Di Sds 018 Plus Avicena Tahun Ajaran 2020/2021. Jurnal Pendidikan MINDA. Vo.2, Nomor 2, April 2021. 
Trismanto. (2017). Keterampilan menulis dan permasalahanya. Jurnal Bangun Rekaprima. Vol.3: 62-67.

Yunus, Mohammad. 2007. Keterampilan Dasar Menulis. Jakarta : Universitas terbuka.

Zuchdi, Darmiyati. (2008). Strategi Meningkatkan Kemampuan Membaca. Yogyakarta: UNY Press.

Zulkarnaini. (2011). Model Kooperatif Tipe Think Talk Write(TTW) untuk Meningkatkan Kemampuan Menulis Karangan Deskripsi dan Berpikir Kritis. Jurnal.Upi.Edu, 11(2), 144153. Retrieved from http://jurnal.upi.edu/view/676.pdf 